\title{
ANALISIS PROYEKSI KEBUTUHAN AIR PADA SISTEM PENYEDIAAN AIR MINUM REGIONAL KOTA TARAKAN DAN KABUPATEN BULUNGAN
}

\author{
Niyar Candra Agustin ${ }^{1}$, Widi Astuti ${ }^{2}$, Eny Apriyanti ${ }^{3}$ \\ ${ }^{1,2}$ Fakultas Teknik, Universitas Pandanaran \\ Jalan Banjarsari Barat No. 1 Pedalangan, Banyumanik, Semarang, Indonesia \\ Email ${ }^{1)}$ : niyaragustin@gmail.com \\ Email2): widi_unp@yahoo.co.id \\ Email ${ }^{3)}$ : enyapriyanti@unpand.ac.id
}

\begin{abstract}
ABSTRAK
Pengembangan dan pertumbuhan penduduk yang terus meningkat akan meyebabkan kebutuhan akan air bersih meningkat. Dalam rangka memenuhi kebutuhan air bersih yang semakin meningkat, di mana debit sumber air yang mengalami penurunan tiap tahunnya maka PDAM Kota Tarakan perlu mengkaji kembali kebutuhan air bersihnya. Tujuan penelitian ini adalah menganalisis proyeksi untuk kebutuhan air di Kota Tarakan dan kabupaten Bulungan. Proyeksi jumlah penduduk dianalisis menggunakan metode geometrik. Berdasarkan hasil analisis, proyeksi kebutuhan air rata-rata di Kota Tarakan hingga tahun 2036 sebanyak 1282 liter/detik terdiri dari kebutuhan air domestik sebesar 854,58 liter/detik, kebutuhan air non domestik sebesar 213,64 liter/detik, proyeksi kehilangan air sebesar 213,64 liter/detik. Kebutuhan air baku di Kota Tarakan hingga tahun 2036 sebanyak 899,69 liter/detik. Sedangkan proyeksi kebutuhan air rata-rata di Kabupaten Bulungan hingga tahun 2036 sebanyak 92, 74 liter/detik terdiri dari kebutuhan air domestik sebesar 63,96 liter/detik, kebutuhan air non domestic sebesar15,99 liter/detik dan proyeksi kehilangan air sebesar 12,79 liter/detik.. Kebutuhan air baku di Kabupaten Bulungan hingga tahun 2036 sebanyak 98,37 liter/detik
\end{abstract}

Kata kunci: proyeksi; kebutuhan air; pertambahan penduduk; Tarakan; Bulungan

\section{PENDAHULUAN}

Pada saat ini, pertumbuhan penduduk Indonesia sudah mencapai angka yang cukup besar. Seiring dengan bertambahnya jumlah penduduk, jumlah kebutuhan hidup yang harus dipenuhi juga semakin besar. Salah satu kebutuhan hidup yang utama yaitu kebutuhan akan air bersih. Air merupakan zat yang sangat diperlukan oleh manusia, hewan, dan tanaman serta sumber energi untuk berbagai keperluan yang lain (Arsyad, 1989). Masalah penyediaan air bersih saat ini menjadi perhatian khusus negara-negara maju maupun negara yang sedang berkembang. Indonesia sebagai salah satu negara berkembang, tidak lepas dari permasalahan penyediaan air bersih bagi masyarakatnya Salah satu masalah pokok yang dihadapi adalah kurang tersedianya sumber air bersih, belum meratanya pelayanan penyediaan air bersih terutama di pedesaan dan sumber air bersih yang ada belum dimanfaatkan secara maksimal. Di kota-kota besar sumber air bersih yang dimanfaatkan oleh PDAM

Penyediaan infrastruktur air minum menjadi prasyarat bagi kehidupan masyarakat yang berkelanjutan. Ketersediaan sistem air minum sangat berpengaruh terhadap pertumbuhan ekonomi regional, serta peningkatan kualitas hidup masyarakat dan lingkungan. Faktor utama yang menentukan besarnya kebutuhan air adalah pertumbuhan penduduk (Zulkipli dkk., 2011). Pertambahan jumlah penduduk yang smakin meningkat dapat mempengaruhi kebutuhan air yang diperlukan dimasa yang akan datang (Halim dkk, 2013). Permasalahan yang dihadapi dalam penyediaan sistem air minum adalah terjadinya kesenjangan antara kebutuhan 
dengan tingkat pelayanan baik di Perkotaan maupun di Perdesaan, tidak meratanya keberadaan sarana dan prasarana air minum, pengelolaan yang kurang efisien, serta kurangnya dana baik untuk pengembangan maupun untuk pengelolaan.

Hingga kini, penyediaan air bersih untuk masyarakat di Indonesia masih diperhadapkan pada beberapa permasalahan yang cukup kompleks dan sampai saat ini belum dapat diatasi sepenuhnya. Salah satu masalah yang masih dihadapi sampai saat ini yakni masih kurangnya tingkat pelayanan air bersih untuk masyarakat. Disisi lain ketersediaan sumber daya alam pun memiliki dampak untuk keberlangsungan suatu daerah. Salah satu sumber daya alam yang sangat penting adalah sumber daya air. Dengan adanya pengembangan dan pertumbuhan penduduk yang terus meningkat akan meyebabkan kebutuhan akan air bersih meningkat (Wahyuni, 2017). Pembangunan berwawasan lingkungan sebagai upaya sadar dan terencana yang memadukan lingkungan hidup termasuk sumber daya air di dalamnya ke dalam proses pembangunan untuk menjamin kemampuan, kesejahteraan dan kualitas hidup (Subekti, 2013). Untuk itu diperlukan adanya penyediaan air bersih yang secara kualitas dapat memenuhi standar air bersih yang berlaku dan secara kuantitas harus dapat memenuhi kebutuhan masyarakat disuatu daerah secara berkelanjutan sehingga aktivitas dapat berjalan dengan baik.

Sistem Penyediaan Air Minum (SPAM) saat ini mempunyai tantangan yang berat, mengingat beberpa hal yang ke depan harus dipikirkan. Antara laju pertumbuhan penduduk yang terus meningkat. Sementara akses masyarakat terhadap sumber air minum yang aman semakin terbatas akibat belum terkendalinya pencemaran lingkungan perkotaan.

Dalam rangka memenuhi kebutuhan air bersih yang semakin meningkat, di mana debit sumber air yang mengalami penurunan tiap tahunnya maka PDAM Kota Tarakan perlu mengkaji kembali kebutuhan air bersihnya. Mengingat sumber air baku di Kota Tarakan juga sudah terbatas maka untuk memenuhi kebutuhan air serta guna meningkatkan cakupan layanan perlu adanya upaya pengembangan SPAM Regional. Sistem tersebut mencakup Regional Kabupaten Bulungan dan Kota Tarakan.

\section{METODOLOGI}

\section{Menghitung Kebutuhan Air Bersih}

Secara umum kebutuhan air dalam perencanaan sistem penyediaan air bersih dipengaruhi oleh keadaan daerah perencanaan, yaitu :

- Iklim.

- Standar kehidupan.

- Jenis aktivitas.

- Ketersediaan sistem penyediaan air perorangan.

- Harga air.

Agar pelayanan air bersih memenuhi syarat tahapan pelayanan yang direncanakan, maka dibutuhkan sumber air dimana segi kuantitas memenuhi syarat, atau secara khusus dinyatakan bahwa kapasitas sumber air harus lebih besar dari kapasitas kebutuhan air pada hari maksimum.

\section{Menghitung Proyeksi Penduduk}

Penduduk merupakan faktor utama dalam perencanaan, karena suatu perencanaan yang disusun untuk keperluan pada massa datang didasari oleh pengetahuan tentang masalah yang sama pada masa sebelumnya. Perkembangan kehidupan dan semua aktivitas merupakan hal yang penting dalam Sistem Penyediaan Air Minum. Angka pertambahan penduduk tidak lepas dari datadata penduduk sebelumnya. Banyak faktor yang mempengaruhi angka pertambahan penduduk seperti masalah kesehatan, sosial, ekonomi, politik dan lain-lain. Populasi berubah dengan angka-angka kematian, kelahiran dan perpindahan penduduk.Jadi faktor-faktor seperti kelahiran, kematian dan migrasi. Proyeksi penduduk berguna untuk memperkirakan kebutuhan air di masa akan 
datang dan perkiraan timbulan air buangan akibat pemakain air tersebut, dengan demikian dapat memberikan tahap perencanaan dan perkiraan pembiyaan pembangunan.

Adapun cara-cara yang diambil untuk menghitung proyeksi penduduk tergantung oleh beberapa hal berikut, diantaranya:

- Keadaan dan jenis kota.

- Rencana pengembangan kota.

- Data kependudukan yang ada.

Pertumbuhan penduduk merupakan salah satu faktor penting dalam perencanaan kebutuhan air bersih. Dalam kajian ini, proyeksi jumlah penduduk digunakan sebagai dasar untuk menghitung tingkat kebutuhan air bersih pada masa mendatang. Perkiraan jumlah penduduk disuatu daerah dan pada tahun tertentu dapat dilakukan apabila diketahui tingkat pertumbuhan penduduknya. Perkiraan jumlah penduduk dimasa mendatang dilakukan dengan menggunakan Metode Geometrik.

Metode ini merupakan salah satu yang paling banyak digunakan dalam perhitungan pertumbuhan penduduk. Dengan menggunakan metode geometrik, maka perkembangan penduduk suatu daerah dapat dihitung dengan formula sebagai berikut:

dengan:

$$
\mathbf{P}_{\mathrm{t}}=\mathbf{P}_{\mathbf{o}}(\mathbf{1}+\mathbf{r})^{\mathbf{n}}
$$

$\mathrm{P}_{\mathrm{t}}=$ jumlah penduduk pada akhir tahun ke $-\mathrm{n}$

$\mathrm{P}_{\mathrm{o}}=$ jumlah penduduk pada tahun yang ditinjau

$\mathrm{r}=$ angka pertumbuhan penduduk tiap tahun

$\mathrm{n}=$ jumlah tahun proyeksi

\section{Menghitung Proyeksi Kebutuhan Air Hingga Tahun Rencana}

Kebutuhan air untuk sistem penyediaan air bersih terbagi dalam beberapa jenis kebutuhan :

- Rumah tangga (domestik)

- Non domestik (sosial, industri, peribadatan, pendidikan, kesehatan)

- Kehilangan air Untuk kota - kota katagori I, II dan III kebutuhan non rumah tangga ditetapkan menurut hasil survey suatu kota yang bersangkutan dikaitkan dengan master plan kota, sedangkan untuk kota - kota katagori IV, kebutuhan non rumah tangga ditetapkan sebesar $10 \%$ dari kebutuhan rumah tangga dan untuk katagori V ditentukan sebesar 10\% dari kebutuhan rumah tangga.

- Tingkat Pelayanan

Pelayanan air bersih pada umumnya dilayani melalui dua cara yaitu sambungan langsung (sambungan rumah/SR) dan hidran umum (HU), dengan proporsi pelayanan $70: 30,80$ : 20 atau $90: 10$, tergantung kondisi daerah yang bersangkutan.

- Kehilangan Air

Kehilangan air yang disebabkan kebocoran teknis maupun administrasi dihitung dengan perkiraan sebesar $20 \%$ dari total kebutuhan rata-rata.

- Fluktuasi Penggunaan Air

Fluktuasi pemakaian air didasarkan pada :

1) Kebutuhan air rata-rata

2) Kebutuhan hari maksimum (Q max

Qmax $=1,05-1.15 \times$ kebutuhan air ratarata

3) Kebutuhan jam puncak

Qpeak $=1,50-1,75 \times$ kebutuhan air ratarata

Tabel 1. Kebutuhan Air Bersih Berdasarkan Jenis Kota Dan Jumlah Penduduk

\begin{tabular}{clcc}
\hline Kategori Kota & \multicolumn{1}{c}{ Jenis Kota } & $\begin{array}{c}\text { Jumlah penduduk } \\
\text { (jiwa) }\end{array}$ & $\begin{array}{c}\text { Kebutuhan air } \\
\text { (L/or/hari) }\end{array}$ \\
\hline I & Metropolitan & $>1.000 .000$ & 190 \\
\hline II & Besar & $500.000-1.000 .000$ & 170 \\
\hline III & Sedang & $150.000-500.000$ & 150 \\
\hline IV & Kecil & $20.000-100.000$ & 130 \\
\hline V & Ibukota Kecamatan & $10.000-20.000$ & 100 \\
\hline
\end{tabular}


Tabel 2. Kebutuhan Air Bersih Berdasarkan Jenis Kota

\begin{tabular}{lccc}
\multicolumn{1}{c}{ Jenis Kota } & $\begin{array}{c}\text { Sambungan Rumah } \\
\text { (1/org/hari) }\end{array}$ & $\begin{array}{c}\text { Sambungan Pekarangan } \\
\text { (l/org/hari) }\end{array}$ & $\begin{array}{c}\text { Hidran Umum } \\
\text { (L/org/hari) }\end{array}$ \\
\hline Besar & $>150$ & - & - \\
\hline Sedang & 100 & 60 & 30 \\
\hline Kecil & 60 & 60 & 30 \\
\hline IKK & 60 & - & 30 \\
\hline Sum
\end{tabular}

Sumber : Dept. Pekerjaan Umum, Dirjen Cipta Karya

\section{HASIL DAN PEMBAHASAN}

\section{Proyeksi Penduduk}

Penduduk Kawasan Perencanaan

Hasil perhitungan proyeksi penduduk di Kota Tarakan dan Kabupaten Bulungan, ditunjukkan pada Tabel 3 ..

Hasil proyeksi penduduk di Kota Tarakan hingga tahun 2036 sebanyak 535.039 jiwa dengan laju pertumbuhan penduduk ratarata sebesar 4\%. Sedangkan proyeksi jumlah penduduk di Kecamatan Sekatak dan Kecamatan Tanjung Palas Utara (Kabupaten Bulungan) hingga tahun 2036 sebesar $\mathbf{3 6 . 8 4 1}$ jiwa.
Rencana Daerah Pelayanan

Rencana daerah layanan untuk SPAM Regional Bulungan - Tarakan meliputi daerah berikut:

a. Kabupaten Bulungan

1) Kecamatan Sekatak

2) Kecamatan Tanjung Palas

b. Kota Tarakan

1) Kecamatan Tarakan Utara

2) Kecamatan Tarakan Timur

3) Kecamatan Tarakan Barat

4) Kecamatan Tarakan Tengah

Tabel 3. Proyeksi Penduduk Kota Tarakan dan Kab. Bulungan hingga Tahun 2036

\begin{tabular}{clcc}
\hline \multirow{2}{*}{ Kota/Kabupaten } & \multicolumn{1}{c}{ Kecamatan } & $\begin{array}{c}\text { Jumlah Penduduk Tahun } \\
\text { 2036 (jiwa) }\end{array}$ & $\begin{array}{c}\text { Jumlah } \\
\text { (jiwa) }\end{array}$ \\
\cline { 2 - 3 } Kota Tarakan & Tarakan Timur & 120.613 & 535.039 \\
& Tarakan Tengah & 170.115 & \\
\cline { 2 - 3 } & Tarakan Barat & 190.145 & \\
\cline { 2 - 3 } & TarakanUtara & 61.857 & \multirow{2}{*}{36.841} \\
\cline { 2 - 3 } Kab. Bulungan & Sekatak & 12.037 & \\
\cline { 2 - 3 } & Tanjung Palas Utara & 24.804 & \\
\hline
\end{tabular}

Sumber: Perhitungan Penyusun 2017

Proyeksi Kebutuhan Air Minum

Perhitungan kebutuhan air bersih didasarkan pada jumlah penduduk yang akan dilayani, dan rata-rata kebutuhan air bersih pada setiap orang. Untuk mengetahui kebutuhan hari maksimum dan kebutuhan jam puncak adalah nilai faktor hari maksimum dan nilai faktor jam maksimum. Dalam menghitung kapasitas produksi harus memperhatikan kondisi sebagai berikut: a. Kebutuhan air untuk instalasi misalnya untuk pencucian filter (backwashing), melarutkan bahan kimia, keperluan kantor dan lain-lain. Pada umumnya kebutuhan air untuk instalasi sekitar 10\% dari kapasitas pengolahan.

b. Kehilangan air di sistem distribusi, misalnya pada saat pemasangan, penggantian dan penambahan pipa distribusi, kebocoran teknis karena sambungan liar, keperluan pemadam kebakaran, menyiram tanaman dan lain- 
lain. Umumnya kehilangan air ini sekitar $30 \%$ dari kapasitas pengolahan.

Kebutuhan air dibedakan menjadi kebutuhan :

a. Domestik meliputi:

1) Rumah tangga;

2) Sosial.

b. Non domestik meliputi:

1) Komersil;

2) Perkotaan;

3) Fasilitas umum;

4) Industri;

5) Pelabuhan dan sebagainya.

Beberapa asumsi yang digunakan dalam perhitungan proyeksi kebutuhan air di Kota Tarakan dan Kabupaten Bulungan adalah sebagai berikut:

a. Kebutuhan air bersih untuk tiap orang menggunakan standar $130 \mathrm{lt} / \mathrm{hr} / \mathrm{org}$, pada tahun 2019 standar kebutuhan air bersih diasumsikan meningkat menjadi $150 \mathrm{lt} / \mathrm{hr} / \mathrm{org}$.

b. Satu sambungan rumah melayani 6 jiwa / KK.

c. Kebutuhan air non domestik sebesar $20 \%$ dari kebutuhan air domestik.

d. Target pelayanan sistem perpipaan diharapkan tahun 2021 mencapai 100\% hingga akhir tahun perencanaan.

e. Prosentase kehilangan air ditargetkan sebesar $20 \%$ di akhir tahun perencanaan.

f. Faktor koefisien kebutuhan air maksimum sebesar 1,15.

g. Faktor koefisien kebutuhan air jam puncak sebesar 1,5.

Hasil perhitungan kebutuhan air minum di Kota Tarakan dan 2 (dua) kecamatan di Kabupaten Bulungan, sebagaimana yang terdapat pada Tabel 4. dan 5.

\section{KESIMPULAN}

Proyeksi kebutuhan air rata-rata di Kota Tarakan hingga tahun 2036 sebanyak 1282 liter/detik terdiri dari kebutuhan air domestik sebesar 854,58 liter/detik, kebutuhan air non domestik sebesar 213,64 liter/detik, proyeksi kehilangan air sebesar 213,64 liter/detik. Kebutuhan air baku di Kota Tarakan hingga tahun 2036 sebanyak 899,69 liter/detik

Sedangkan proyeksi kebutuhan air ratarata di Kabupaten Bulungan hingga tahun 2036 sebanyak 92, 74 liter/detik terdiri dari kebutuhan air domestik sebesar 63,96 liter/detik, kebutuhan air non domestic sebesar15,99 liter/detik dan proyeksi kehilangan air sebesar 12,79 liter/detik.. Kebutuhan air baku di Kabupaten Bulungan hingga tahun 2036 sebanyak 98,37 liter/detik

\section{DAFTAR PUSTAKA}

Asryad, S., 1989, Konservasi Tanah dan Air. IPB Press. Bogor

Ditjen Cipta Karya, 1997, Kriteria Perencanaan Ditjen Cipta Karya Dinas PU. Jakarta: Ditjen Cipta Karya.

Halim, F., Jasin, M. I., dan Kawet, L., 2013, Pengembangan Sistem Penyediaan Air Bersih, Sipil Statik, 1: 444

Subekti, S.,2012, Studi identifikasi kebutuhan dan potensi air baku air minum kabupaten pasuruan, JURNAL ILMIAH MOMENTUM, 8:2.

Wahyuni, A., dan Junianto, 2017, Analisa Kebutuhan Air Bersih Kota Batam Pada Tahun 2025, Tapak, 6: 116-126.

Zulkifli., Soetopo, W., dan Prasetyo H., 2012, Analisa Neraca Air Permukaan DAS Renggung untuk Memenuhi Kebutuhan Air Irigasi dan Domestik Penduduk Kabupaten Lombok Tengah, Teknik Pengairan, 3:89. 
Tabel 4.Proyeksi Kebutuhan Air Minum di Kota Tarakan hingga Tahun 2036

\begin{tabular}{|c|c|c|c|c|c|c|c|c|c|c|c|c|c|}
\hline \multirow{2}{*}{ No. } & \multirow{2}{*}{ Uraian } & \multirow{2}{*}{ Satuan } & \multicolumn{2}{|c|}{ Eksisting } & \multicolumn{9}{|c|}{ Proyeksi Tahun } \\
\hline & & & $2015^{*}$ & $2016^{*}$ & 2017 & 2018 & 2019 & 2020 & 2021 & 2022 & 2023 & 2024 & 2025 \\
\hline $\mathbf{A}$ & KEPENDUDUKAN & & & & & & & & & & & & \\
\hline & Jumlah Penduduk & jiwa & 235.570 & 244.185 & 253.952 & 264.110 & 274.675 & 285.662 & 297.088 & 308.972 & 321.331 & 334.184 & 347.551 \\
\hline B & KEBUTUHAN DOMESTIK & & & & & & & & & & & & \\
\hline & Tingkat Pelayanan & $\%$ & 49,16 & 51,61 & 54,25 & 56,71 & 59 & 61,15 & 63,15 & 65,51 & 67,73 & 69,83 & 71,8 \\
\hline & Penduduk Terlayani & jiwa & 115.806 & 126.024 & 137.769 & 149.777 & 162.058 & 174.682 & 187.611 & 202.408 & 217.637 & 233.361 & 249.542 \\
\hline & Jumlah Penduduk Per SR & jiwa & 6 & 6 & 6 & 6 & 6 & 6 & 6 & 6 & 6 & 6 & 6 \\
\hline & Jumlah SR & unit & 19.301 & 21.004 & 22.962 & 24.963 & 27.010 & 29.114 & 31.269 & 33.735 & 36.273 & 38.893 & 41.590 \\
\hline & Penambahan SR & unit & 1.968 & 1.925 & 1.958 & 2.001 & 2.047 & 2.104 & 2.155 & 2.466 & 2.538 & 2.621 & 2.697 \\
\hline & Pemakaian Per Orang & It/ org/ hari & 150 & 150 & 150 & 150 & 150 & 150 & 150 & 150 & 150 & 150 & 150 \\
\hline & Kebutuhan Air Domestik & It detik & 201,05 & 218,79 & 239,18 & 260,03 & 281,35 & 303,27 & 325,71 & 351,40 & 377,84 & 405,14 & 433,23 \\
\hline C & KEBUTUHAN NON DOMESTIK & & & & & & & & & & & & \\
\hline & Prosentase Kebutuhan Non Domestik & $\%$ & $20 \%$ & $20 \%$ & $20 \%$ & $20 \%$ & $20 \%$ & $25 \%$ & $25 \%$ & $25 \%$ & $25 \%$ & $25 \%$ & $25 \%$ \\
\hline & Total Kebutuhan Non Domestik & Itdetik & 40,21 & 43,76 & 47,84 & 52,01 & 56,27 & 75,82 & 81,43 & 87,85 & 94,46 & 101,29 & 108,31 \\
\hline D & KEBUTUHAN AIR TOTAL & It/detik & 241,26 & 262,55 & 287,02 & 312,04 & 337,62 & 379,08 & 407,14 & 439,25 & 472,30 & 506,43 & 541,54 \\
\hline $\mathrm{E}$ & NRW Distribusi & & & & & & & & & & & & \\
\hline & $\%$ NRW Distribusi & $\%$ & $39 \%$ & $39 \%$ & $33 \%$ & $26 \%$ & $25 \%$ & $20 \%$ & $20 \%$ & $20 \%$ & $20 \%$ & $20 \%$ & $20 \%$ \\
\hline & Jumlah NRW Distribusi & It/detik & 94,09 & 102,39 & 94,72 & 81,13 & 84,41 & 75,82 & 81,43 & 87,85 & 94,46 & 101,29 & 108,31 \\
\hline $\mathbf{F}$ & KEBUTUHAN AIR RATA-RATA (D+E) & It/detik & 335,36 & 364,94 & 381,74 & 393,16 & 422,03 & 454,90 & 488,57 & 527,10 & 566,76 & 607,71 & 649,85 \\
\hline $\mathbf{G}$ & KEBUTUHAN HARI MAKSIMUM & & & & & & & & & & & & \\
\hline & Faktor Koefisien & & 1,2 & 1,2 & 1,2 & 1,2 & 1,2 & 1,2 & 1,2 & 1,2 & 1,2 & 1,2 & 1,2 \\
\hline & Kebutuhan Air & It/detik & 402,43 & 437,93 & 458,08 & 471,80 & 506,43 & 545,88 & 586,29 & 632,52 & 680,12 & 729,25 & 779,82 \\
\hline $\mathrm{H}$ & KEBUTUHAN JAM PUNCAK & & & & & & & & & & & & \\
\hline & Faktor Koefisien & & 1,75 & 1,75 & 1,75 & 1,75 & 1,75 & 1,75 & 1,75 & 1,75 & 1,75 & 1,75 & 1,75 \\
\hline & Kebutuhan Air & Itdetik & 586,87 & 638,65 & 668,04 & 688,04 & 738,55 & 796,08 & 855,00 & 922,43 & 991,84 & $1.063,49$ & $1.137,24$ \\
\hline I & KEBUTUHAN AIR RENCANA & It/detik & 335,36 & 364,94 & 381,74 & 393,16 & 422,03 & 454,90 & 488,57 & 527,10 & 566,76 & 607,71 & 649,85 \\
\hline $\mathrm{J}$ & |KETERSEDIAAN AIR DISTRIBUSI & L/dtk & 374,09 & 374,09 & 424,09 & 424,09 & 424,09 & 424,09 & 424,09 & 424,09 & 424,09 & 424,09 & 424,09 \\
\hline $\mathrm{K}$ & KEKURANGAN AIR & L/dtk & $(38,73)$ & $(9,15)$ & $(42,35)$ & $(30,93)$ & $(2,06)$ & 30,81 & 64,48 & 103,01 & 142,67 & 183,62 & 225,76 \\
\hline $\bar{L}$ & KEHILANGAN PRODUKSI & & & & & & & & & & & & \\
\hline & $\%$ Kehilangan Produksi & $\%$ & 3,62 & 3,78 & 3,27 & 3,27 & 3,27 & 3,27 & 3,27 & 3,27 & 3,27 & 3,27 & 3,27 \\
\hline & Jumlah Kehilangan Produksi & L/dtk & 12,14 & 13,79 & 12,48 & 12,86 & 13,80 & 14,88 & 15,98 & 17,24 & 18,53 & 19,87 & 21,25 \\
\hline M & KEBUTUHAN AIR BAKU & L/dtk & 50,87 & 22,94 & 54,84 & 43,78 & 15,86 & 45,69 & 80,46 & 120,25 & 161,21 & 203,49 & 247,01 \\
\hline
\end{tabular}


Lanjutan tabel:

\begin{tabular}{|c|c|c|c|c|c|c|c|c|c|c|c|c|c|}
\hline \multirow{2}{*}{ No. } & \multirow{2}{*}{ Uraian } & \multirow{2}{*}{ Satuan } & \multicolumn{11}{|c|}{ Tahun Proyeksi } \\
\hline & & & 2026 & 2027 & 2028 & 2029 & 2030 & 2031 & 2032 & 2033 & 2034 & 2035 & 2036 \\
\hline \multirow[t]{2}{*}{$\bar{A}$} & KEPENDUDUKAN & & & & & & & & & & & & \\
\hline & Jumlah Penduduk & jiwa & 361.453 & 375.912 & 390.948 & 406.586 & 422.849 & 439.763 & 457.354 & 475.648 & 494.674 & 514.461 & 535.039 \\
\hline \multirow[t]{8}{*}{$\mathrm{B}$} & KEBUTUHAN DOMESTIK & & & & & & & & & & & & \\
\hline & Tingkat Pelayanan & $\%$ & 73,67 & 75,85 & 77,92 & 79,88 & 81,75 & 83,52 & 85,58 & 87,55 & 89,43 & 91,22 & 92 \\
\hline & Penduduk Terlayani & jiwa & 266.283 & 285.129 & 304.627 & 324.781 & 345.679 & 367.290 & 391.403 & 416.430 & 442.387 & 469.291 & 492.236 \\
\hline & Jumlah Penduduk Per SR & jiwa & 6 & 6 & 6 & 6 & 6 & 6 & 6 & 6 & 6 & 6 & 6 \\
\hline & Jumlah SR & unit & 44.380 & 47.521 & 50.771 & 54.130 & 57.613 & 61.215 & 65.234 & 69.405 & 73.731 & 78.215 & 82.039 \\
\hline & Penambahan SR & unit & 2.790 & 3.141 & 3.250 & 3.359 & 3.483 & 3.602 & 4.019 & 4.171 & 4.326 & 4.484 & 3.824 \\
\hline & Pemakaian Per Orang & It/ org/ hari & 150 & 150 & 150 & 150 & 150 & 150 & 150 & 150 & 150 & 150 & 150 \\
\hline & Kebutuhan Air Domestik & It detik & 462,30 & 495,02 & 528,87 & 563,86 & 600,14 & 637,66 & 679,52 & 722,97 & 768,03 & 814,74 & 854,58 \\
\hline \multirow[t]{3}{*}{$\mathrm{C}$} & KEBUTUHAN NON DOMESTIK & & & & & & & & & & & & \\
\hline & Prosentase Kebutuhan Non Domestik & $\%$ & $25 \%$ & $25 \%$ & $25 \%$ & $25 \%$ & $25 \%$ & $25 \%$ & $25 \%$ & $25 \%$ & $25 \%$ & $25 \%$ & $25 \%$ \\
\hline & Total Kebutuhan Non Domestik & Itdetik & 115,57 & 123,75 & 132,22 & 140,96 & 150,03 & 159,41 & 169,88 & 180,74 & 192,01 & 203,69 & 213,64 \\
\hline D & KEBUTUHAN AIR TOTAL & Itdetik & 577,87 & 618,77 & 661,08 & 704,82 & 750,17 & 797,07 & 849,40 & 903,71 & 960,04 & $1.018,43$ & $1.068,22$ \\
\hline \multirow[t]{3}{*}{$\mathrm{E}$} & NRW Distribusi & & & & & & & & & & & & \\
\hline & $\%$ NRW Distribusi & $\%$ & $20 \%$ & $20 \%$ & $20 \%$ & $20 \%$ & $20 \%$ & $20 \%$ & $20 \%$ & $20 \%$ & $20 \%$ & $20 \%$ & $20 \%$ \\
\hline & Jumlah NRW Distribusi & Itdetik & 115,57 & 123,75 & 132,22 & 140,96 & 150,03 & 159,41 & 169,88 & 180,74 & 192,01 & 203,69 & 213,64 \\
\hline $\mathrm{F}$ & KEBUTUHAN AIR RATA-RATA (D+E) & Itdetik & 693,44 & 742,52 & 793,30 & 845,78 & 900,21 & 956,49 & $1.019,28$ & $1.084,45$ & $1.152,05$ & $1.222,11$ & $1.281,87$ \\
\hline \multirow[t]{3}{*}{$\mathbf{G}$} & KEBUTUHAN HARI MAKSIMUM & & & & & & & & & & & & \\
\hline & Faktor Koefisien & & 1,2 & 1,2 & 1,2 & 1,2 & 1,2 & 1,2 & 1,2 & 1,2 & 1,2 & 1,2 & 1,2 \\
\hline & Kebutuhan Air & Itdetik & 832,13 & 891,03 & 951,96 & $1.014,94$ & $1.080,25$ & $1.147,78$ & $1.223,14$ & $1.301,34$ & $1.382,46$ & $1.466,54$ & $1.538,24$ \\
\hline \multirow[t]{3}{*}{$\mathrm{H}$} & KEBUTUHAN JAM PUNCAK & & & & & & & & & & & & \\
\hline & Faktor Koefisien & & $\overline{1,75}$ & $\overline{1,75}$ & 1,75 & 1,75 & $\overline{1,75}$ & 1,75 & 1,75 & 1,75 & $\overline{1,75}$ & $\overline{1,75}$ & 1,75 \\
\hline & Kebutuhan Air & Itddetik & $1.213,53$ & $1.299,42$ & $1.388,27$ & $1.480,12$ & $1.575,36$ & $1.673,85$ & $1.783,74$ & $1.897,79$ & $2.016,09$ & $2.138,70$ & $2.243,26$ \\
\hline $\mathrm{I}$ & KEBUTUHAN AIR RENCANA & It/detik & 693 & 743 & 793 & 846 & 900 & 956 & 1.019 & 1.084 & 1.152 & 1.222 & 1.282 \\
\hline $\mathrm{J}$ & KETERSEDIAAN AIR DISTRIBUSI & L/dtk & 424,09 & 424,09 & 424,09 & 424,09 & 424,09 & 424,09 & 424,09 & 424,09 & 424,09 & 424,09 & 424,09 \\
\hline $\mathrm{K}$ & KEKURANGAN AIR & L/dtk & 269 & 318 & 369 & 422 & 476 & 532 & 595 & 660 & 728 & 798 & 858 \\
\hline $\mathrm{L}$ & KEHILANGAN PRODUKSI & & & & & & & & & & & & \\
\hline & $\%$ Kehilangan Produksi & 7 & $3,27 \%$ & $3,27 \%$ & $3,27 \%$ & $3,27 \%$ & $3,27 \%$ & $3,27 \%$ & $3,27 \%$ & $3,27 \%$ & $3,27 \%$ & $3,27 \%$ & $3,27 \%$ \\
\hline & Jumlah Kehilangan Produksi & L/dtk & 22,68 & 24,28 & 25,94 & 27,66 & 29,44 & 31,28 & 33,33 & 35,46 & 37,67 & 39,96 & 41,92 \\
\hline $\bar{M}$ & KEBUTUHAN AIR BAKU & L/dtk & 292,03 & 342,71 & 395,15 & 449,35 & 505,55 & \begin{tabular}{|l|l|}
563,67 \\
\end{tabular} & 628,52 & 695,82 & 765,63 & 837,99 & 899,69 \\
\hline
\end{tabular}


Tabel 5. Proyeksi Kebutuhan Air Minum di Kecamatan Sekatak dan Tanjung Palas Utara (Kabupaten Bulungan) hingga Tahun 2036

\begin{tabular}{|c|c|c|c|c|c|c|c|c|c|c|c|c|c|}
\hline \multirow{2}{*}{ No } & \multirow{2}{*}{ Uraian } & \multirow{2}{*}{ Satuan } & \multicolumn{2}{|c|}{ Eksisting } & \multicolumn{9}{|c|}{ Proyeksi Tahun } \\
\hline & & & 2015 & 2016 & 2017 & 2018 & 2019 & 2020 & 2021 & 2022 & 2023 & 2024 & 2025 \\
\hline $\mathbf{A}$ & KEPENDUDUKAN & & & & & & & & & & & & \\
\hline 1 & Jumlah Penduduk Kabupaten Bulungan & jiwa & 154.934 & 173.844 & 179.470 & 185.096 & 190,722 & 196.347 & 201.973 & 207.599 & 213.224 & 218.850 & 224.476 \\
\hline & $\begin{array}{l}\text { Jumlah Penduduk Kecamatan Sekatak dan } \\
\text { Kecamatan Tanjung Palas Utara }\end{array}$ & jiwa & 20.652 & 21.185 & 21.737 & 22.307 & 22.897 & 23.508 & 24.141 & 24.795 & 25.473 & 26.175 & 26.901 \\
\hline B & KEBUTUHAN DOMESTIK & & & & & & & & & & & & \\
\hline 1 & Tingkat Pelayanan Kabupaten Bulungan* & $\%$ & $51,77 \%$ & $70,00 \%$ & $75,00 \%$ & $75,00 \%$ & $80,00 \%$ & $80,00 \%$ & $90,00 \%$ & $90,00 \%$ & $90,00 \%$ & $90,00 \%$ & $90,00 \%$ \\
\hline 2 & Penduduk Terlayani Kabupaten Bulungan & jiwa & 80.209 & 121.691 & 134.603 & 138.822 & 152,578 & 157.078 & 181.776 & 186.839 & 191.902 & 196.965 & 202.028 \\
\hline 3 & $\begin{array}{l}\text { Tingkat Pelayanan Kecamatan Sekatak dan } \\
\text { Kecamatan Tanjung Palas Utara }\end{array}$ & $\%$ & $0.00 \%$ & $0.00 \%$ & $8,13 \%$ & $15,80 \%$ & $23,05 \%$ & $29,90 \%$ & $36,40 \%$ & $43 \%$ & $48,43 \%$ & $54,01 \%$ & $59,33 \%$ \\
\hline & $\begin{array}{l}\text { Penduduk Terlayani Kecamatan Sekatak dan } \\
\text { Kecamatan Tanjung Palas Utara }\end{array}$ & jiwa & 0 & 0 & 1.767 & 3.525 & 5.278 & 7.029 & 8.787 & 10.555 & 12.337 & 14.137 & 15.961 \\
\hline 5 & $\begin{array}{l}\text { Persentase Layanan SPAM Regional terhadap } \\
\text { Tingkat Layanan Kabupaten Bulungan }\end{array}$ & $\%$ & 0 & 0 & 1,31 & $3,14 \%$ & $4,57 \%$ & $5,92 \%$ & $6,40 \%$ & $7,47 \%$ & $8,48 \%$ & $9,44 \%$ & $10,36 \%$ \\
\hline 6 & Jumlah Penduduk Per SR & jiwa & 6 & 6 & 6 & 6 & 6 & 6 & 6 & 6 & 6 & 6 & 6 \\
\hline 7 & Jumlah SR Kabupaten Bulungan & unit & 13.368 & 20.282 & 22.434 & 23.137 & 25 & 26.180 & 30.296 & 31.140 & 31.984 & 32.828 & 33.671 \\
\hline 8 & $\begin{array}{l}\text { Jumlah SR Kecamatan Sekatak dan Kecamatan } \\
\text { Tanjung Palas Utara }\end{array}$ & unit & 0 & 0 & 295 & 587 & 880 & 1.172 & 1.465 & 1.759 & 2.056 & 2.356 & 2.660 \\
\hline 9 & Penambahan SR & unit & 0 & 0 & 388 & 388 & 388 & 388 & 388 & 388 & 388 & 388 & 388 \\
\hline 10 & Pemakaian Per Orang & It/ org/ hari & 150 & 150 & 150 & 150 & 150 & 150 & 150 & 150 & 150 & 150 & 150 \\
\hline 11 & Kebutuhan Air Domestik & It/ detik & 0.00 & 0.00 & 3,07 & 6,12 & 9,16 & 12,20 & 15,26 & 18,33 & 21,42 & 24,54 & 27,71 \\
\hline C & KEBUTUHAN NON DOMESTIK & & & & & & & & & & & & \\
\hline 1 & Prosentase Kebutuhan Non Domestik & $\%$ & $20 \%$ & $20 \%$ & $20 \%$ & $20 \%$ & $20 \%$ & $25 \%$ & $25 \%$ & $25 \%$ & $25 \%$ & $25 \%$ & $25 \%$ \\
\hline & Total Kebutuhan Non Domestik & It/detik & 0.00 & 0.00 & 0,61 & 1,22 & 1,83 & 3,05 & 3,81 & 4,58 & 5,35 & 6,14 & 6,93 \\
\hline $\mathbf{D}$ & KEBUTUHAN AIR TOTAL & It/detik & 0.00 & 0.00 & 3,68 & 7,34 & 11,00 & 15,25 & 19,07 & 22,91 & 26,77 & 30,68 & 34,64 \\
\hline $\mathrm{E}$ & KEHILANGAN AIR & & & & & & & & & & & & \\
\hline 1 & $\%$ Kehilangan Air & $\%$ & $0 \%$ & $0 \%$ & $16 \%$ & $16 \%$ & $16 \%$ & $16 \%$ & $16 \%$ & $16 \%$ & $16 \%$ & $16 \%$ & $16 \%$ \\
\hline 2 & Jumlah Kehilangan Air & It/detik & 0.00 & 0.00 & 0,59 & 1,17 & 1,76 & 2,44 & 3,05 & 3,67 & 4,28 & 4,91 & 5,54 \\
\hline $\mathbf{F}$ & KEBUTUHAN AIR RATA-RATA (D+E) & It/detik & 0.00 & 0.00 & 4,27 & 8,52 & 12,75 & 17,69 & 22,12 & 26,57 & 31,06 & 35,59 & 40,18 \\
\hline $\mathbf{G}$ & KEBUTUHAN HARI MAKSIMUM & & & & & & & & & & & & \\
\hline & Faktor Koefisien & & 1,15 & 1,15 & 1,15 & 1,15 & 1,15 & 1,15 & 1,15 & 1,15 & 1,15 & 1,15 & 1,15 \\
\hline & Kebutuhan Air & It/detik & 0.00 & 0.00 & 4,91 & 9,80 & 14,67 & 20,35 & 25,44 & 30,56 & 35,71 & 40,93 & 46,21 \\
\hline $\mathbf{H}$ & KEBUTUHAN JAM PUNCAK & & & & & & & & & & & & \\
\hline 1 & Faktor Koefisien & & 1,5 & 1,5 & 1,5 & 1,5 & 1,5 & 1,5 & 1,5 & 1,5 & 1,5 & 1,5 & 1,5 \\
\hline & Kebutuhan Air & It/detik & 0 & 0 & 6,41 & 12,78 & 19,13 & 26,54 & 33,18 & 39,86 & 46,58 & 53,38 & 60,27 \\
\hline $\mathrm{I}$ & KEBUTUHAN AIR RENCANA & It/detik & $\mathbf{0}$ & $\mathbf{0}$ & 4,27 & 8,52 & 12,75 & 17,69 & 22,12 & 26,57 & 31,06 & 35,59 & 40,18 \\
\hline $\mathbf{J}$ & KETERSEDIAAN AIR DISTRIBUSI & L/dtk & 0 & 0 & 0 & 0 & 0 & 0 & 0 & 0 & 0 & 0 & 0 \\
\hline $\mathbf{K}$ & KEKURANGAN AIR & L/dtk & 0 & 0 & 4,27 & 8,52 & 12,75 & 17,69 & 22,12 & 26,57 & 31,06 & 35,59 & 40,18 \\
\hline $\mathbf{L}$ & KEHILANGAN PRODUKSI & & & & & & & & & & & & \\
\hline & $\%$ Kehilangan Produksi & $\%$ & $0,00 \%$ & $0,00 \%$ & $6,07 \%$ & $6,07 \%$ & $6,07 \%$ & $6,07 \%$ & $6,07 \%$ & $6,07 \%$ & $6,07 \%$ & $6,07 \%$ & $6,07 \%$ \\
\hline 2 & Jumlah Kehilangan Produksi & L/dtk & 0 & 0 & 0,26 & 0,52 & 0,77 & 1,07 & 1,34 & 1,61 & 1,89 & 2,16 & 2,44 \\
\hline $\mathbf{M}$ & KEBUTUHAN AIR BAKU & L/dtk & 0 & 0 & 4,53 & 9,03 & 13,53 & 18,77 & 23,46 & 28,18 & 32,94 & 37,75 & 42,62 \\
\hline $\mathbf{N}$ & KEBUTUHAN AIR UNTUK KAWASAN INDUSTRI & L/dtk & 0 & 0 & 0 & 0 & 0 & 0 & 50 & 50 & 50 & 50 & 60 \\
\hline 0 & KEBUTUHAN AIR TOTAL & L/dtk & 0 & 0 & 4,53 & 9,03 & 13,53 & 18,77 & 73,46 & 78,18 & 82,94 & 87,75 & 102,62 \\
\hline
\end{tabular}




\begin{tabular}{|c|c|c|c|c|c|c|c|c|c|c|c|c|c|}
\hline \multirow{2}{*}{ No } & \multirow{2}{*}{ Uraian } & \multirow{2}{*}{ Satuan } & \multicolumn{11}{|c|}{ Proyeksi Tahun } \\
\hline & & & 2026 & 2027 & 2028 & 2029 & 2030 & 2031 & 2032 & 2033 & 2034 & 2035 & 2036 \\
\hline $\mathbf{A}$ & KEPENDUDUKAN & & & & & & & & & & & & \\
\hline & Jumlah Penduduk Kabupaten Bulungan & & 230.102 & 235.727 & 241.353 & 246.979 & 252.604 & 25.823 & 263.856 & 269.482 & 275.107 & 280.733 & 286.359 \\
\hline & $\begin{array}{l}\text { Jumlah Penduduk Kecamatan Sekatak dan } \\
\text { Kecamatan Tanjung Palas Utara }\end{array}$ & jiwa & 27.654 & 28.433 & 29.240 & 30.076 & 30.942 & 31.840 & 32.770 & 33.734 & 34.733 & 35.768 & 36.841 \\
\hline B & KEBUTUHAN DOMESTIK & & & & & & & & & & & & \\
\hline & Tingkat Pelayanan Kabupaten Bulungan* & $\%$ & $100 \%$ & $100 \%$ & $100 \%$ & $100 \%$ & $100 \%$ & $100 \%$ & $100 \%$ & $100 \%$ & $100 \%$ & $100 \%$ & $100 \%$ \\
\hline & Penduduk Terlayani Kabupaten Bulungan & jiwa & 230.102 & 235.727 & 241.353 & 246.979 & 252.604 & 25.823 & 263.856 & 269.482 & 275.107 & 280.733 & 286.359 \\
\hline & $\begin{array}{l}\text { Tingkat Pelayanan Kecamatan Sekatak dan } \\
\text { Kecamatan Tanjung Palas Utara }\end{array}$ & $\%$ & $64,39 \%$ & $69,23 \%$ & $73,86 \%$ & $78,29 \%$ & $82,53 \%$ & $86,59 \%$ & $90,49 \%$ & $94,23 \%$ & $97,83 \%$ & $100 \%$ & $100 \%$ \\
\hline & $\begin{array}{l}\text { Penduduk Terlayani Kecamatan Sekatak dan } \\
\text { Kecamatan Tanjung Palas Utara }\end{array}$ & jiwa & 17.806 & 19.684 & 21.597 & 23.547 & 25.537 & 27.570 & 29.654 & 31.787 & 33.979 & 35.768 & 36.841 \\
\hline & $\begin{array}{l}\text { Persentase Layanan SPAM Regional terhadap } \\
\text { Tingkat Layanan Kabupaten Bulungan }\end{array}$ & $\%$ & 7,74 & 8,35 & 8,95 & 9,53 & 10,11 & 106,77 & 11,24 & 11,80 & 12,35 & 12,74 & 12,87 \\
\hline 6 & Jumlah Penduduk Per SR & jiwa & 6 & 6 & 6 & 6 & 6 & 6 & 6 & 6 & 6 & 6 & \\
\hline 7 & Jumlah SR Kabupaten Bulungan & unit & 38.350 & 39.288 & 40.226 & 41.163 & 42.101 & 4.304 & 43.976 & 44.914 & 45.851 & 46.789 & 47.727 \\
\hline & $\begin{array}{l}\text { Jumlah SR Kecamatan Sekatak dan Kecamatan } \\
\text { Tanjung Palas Utara }\end{array}$ & unit & 2.968 & 3.281 & 3.599 & 3.924 & 4.256 & 4.595 & 4.942 & 5.298 & 5.663 & 5.961 & 6.140 \\
\hline 9 & Penambahan SR & unit & 388 & 388 & 388 & 388 & 388 & 388 & 388 & 388 & 388 & 388 & 388 \\
\hline 10 & Pemakaian Per Orang & org/ hari & 150 & 150 & 150 & 150 & 150 & 150 & 150 & 150 & 150 & 150 & 150 \\
\hline 11 & Kebutuhan Air Domestik & It/ detik & 30,91 & 34,17 & 37,49 & 40,88 & 44,33 & 47,86 & 51,48 & 55,19 & 58,99 & 62,10 & 63,96 \\
\hline C & KEBUTUHAN NON DOMESTIK & & & & & & & & & & & & \\
\hline 1 & Prosentase Kebutuhan Non Domestik & 70 & $25 \%$ & $25 \%$ & $25 \%$ & $25 \%$ & $25 \%$ & $25 \%$ & $25 \%$ & $25 \%$ & $25 \%$ & $25 \%$ & $25 \%$ \\
\hline & Total Kebutuhan Non Domestik & It/detik & 7,73 & 8,54 & 9,37 & 10,22 & 11,08 & 11,97 & 12,87 & 13,80 & 14,75 & 15,52 & 15,99 \\
\hline $\mathbf{D}$ & KEBUTUHAN AIR TOTAL & It/detik & 38,64 & 42,72 & 46,87 & 51,10 & 55,42 & 59,83 & 64,35 & 68,98 & 73,74 & 77,62 & 79,95 \\
\hline $\mathrm{E}$ & KEHILANGAN AIR & & & & & & & & & & & & \\
\hline & $\%$ Kehilangan Air & $\%$ & $16 \%$ & $16 \%$ & $16 \%$ & $16 \%$ & $16 \%$ & $16 \%$ & $16 \%$ & $16 \%$ & $16 \%$ & $16 \%$ & $16 \%$ \\
\hline 2 & Jumlah Kehilangan Air & It/detik & 6,18 & 6,83 & 7,50 & 8,18 & 8,87 & 9,57 & 10,30 & 11,04 & 11,80 & 12,42 & 12,79 \\
\hline $\mathbf{F}$ & KEBUTUHAN AIR RATA-RATA (D+E) & It/detik & 44,82 & 49,55 & 54,37 & 59,28 & 64,29 & 69,40 & 74,65 & 80,02 & 85,54 & 90,04 & 92,74 \\
\hline $\mathbf{G}$ & KEBUTUHAN HARI MAKSIMUM & & & & & & & & & & & & \\
\hline & Faktor Koefisien & & 1,15 & 1,15 & 1,15 & 1,15 & 1,15 & 1,15 & 1,15 & 1,15 & 1,15 & 1,15 & 1,15 \\
\hline 2 & Kebutuhan Air & It/detik & 51,55 & 56,98 & 62,52 & 68,17 & 73,93 & 79,81 & 85,85 & 92,02 & 98,37 & 103,55 & 106,65 \\
\hline $\mathbf{H}$ & KEBUTUHAN JAM PUNCAK & & & & & & & & & & & & \\
\hline & Faktor Koefisien & & 1,5 & 1,5 & 1,5 & 1,5 & 1,5 & 1,5 & 1,5 & 1,5 & 1,5 & 1,5 & 1,5 \\
\hline & Kebutuhan Air & It/detik & 67,24 & 74,33 & 81,55 & 88,91 & 96,43 & 104,11 & 111,97 & 120,03 & 128,31 & 135,06 & 139,11 \\
\hline $\mathrm{I}$ & KEBUTUHAN A & It/detik & 44,82 & 49,55 & 54,37 & 59,28 & 64,29 & 69,40 & 74,65 & 80,02 & 85,54 & 90,04 & 92,74 \\
\hline $\mathbf{J}$ & KETERSEDIAAN AIR DISTRIBUSI & L/dtk & 0.00 & 0.00 & 0.00 & 0.00 & 0.00 & 0.00 & 0.00 & 0.00 & 0.00 & 0.00 & 0.00 \\
\hline $\mathbf{K}$ & KEKURANGAN AIR & L/dtk & 44,82 & 49,55 & 54,37 & 59,28 & 64,29 & 69,40 & 74,65 & 80,02 & 85,54 & 90,04 & 92,74 \\
\hline $\mathbf{L}$ & KEHILANGAN PRODUKSI & & & & & & & & & & & & \\
\hline & $\%$ Kehil & $\%$ & $6,07 \%$ & $6,07 \%$ & $6,07 \%$ & $6,07 \%$ & $6,07 \%$ & $6,07 \%$ & $6,07 \%$ & $6,07 \%$ & $6,07 \%$ & $6,07 \%$ & $6,07 \%$ \\
\hline & Jumlah Kehilangan Produksi & L/dtk & 2,72 & 3,01 & 3,30 & 3,60 & 3,90 & 4,21 & 4,53 & 4,86 & 5,19 & 5,47 & 5,63 \\
\hline $\mathbf{M}$ & KEBUTUHAN AIR BAKU & L/dtk & 47,55 & 52,56 & 57,67 & 62,87 & 68,19 & 73,62 & 79,18 & 84,88 & 90,73 & 95,51 & 98,37 \\
\hline $\mathbf{N}$ & KEBUTUHAN AIR UNTUK KAWASAN INDUSTRI & L/dtk & 70 & 80 & 90 & 100 & 100 & 100 & 100 & 100 & 100 & 100 & 100 \\
\hline$\overline{0}$ & KEBUTUHAN AIR TOTAL & L/dtk & 118 & 133 & 148 & 163 & 168 & 174 & 179 & 185 & 191 & 196 & 198 \\
\hline
\end{tabular}

